\title{
Water Relations of Salvia splendens 'Bonfire' as Influenced by Potassium Nutrition and Moisture Stress Conditioning
}

\author{
D. Joseph Eakes ${ }^{1}$, Robert D. Wright ${ }^{2}$, and John R. Seiler ${ }^{3}$ \\ Department of Horticulture, Virginia Polytechnic Institute and State University, Blacksburg, \\ VA 24061
}

\begin{abstract}
Additional index words. water potential, osmotic potential, turgor potential, evapotranspiration
Abstract. The influence of $\mathrm{K}$ nutrition (25, 75, 150, 300, 450, and $600 \mathrm{mg} \mathrm{K} / \mathrm{liter}$ ) and moisture stress conditioning (MSC) (exposing plants to four sublethal dry-down cycles) on leaf water relations, evapotranspiration, growth, and nutrient content was determined for salvia (Salvia splendens F. Sellow 'Bonfire'). Potassium concentration and MSC had an interactive influence on osmotic potential at full $\left(\pi_{100}\right)$ and zero $\left(\pi_{0}\right)$ turgor. Differences in osmotic potential between MSC and non-MSC plants for $\pi_{100}$ and $\pi_{0}$ increased with increasing $\mathrm{K}$ concentration. Increasing $\mathrm{K}$ concentration and MSC resulted in active osmotic adjustment and, consequently, increased cellular turgor potentials. Foliar $\mathrm{K}$ content increased with increasing K concentration and MSC. High K concentrations and MSC both reduced plant evapotranspiration on a per-plant and per-unit-leaf-area basis. Greatest shoot dry weight occurred for plants grown with $300 \mathrm{mg} \mathrm{K} /$ liter and non-MSC. Total leaf area increased with increasing K concentration, but MSC had little effect.
\end{abstract}

Two ways that plants avoid drought stress and maintain turgor are by minimizing transpirational water loss and by osmotic adjustment (Kramer, 1983). Osmotic adjustment in plants is a decrease in cell osmotic potential (increase in solutes) beyond that explained by the concentrating effect on cell solutes by cellular water loss or reductions in cell volume (Jones and Turner, 1980; Kramer, 1983; Mengel and Kirkby, 1982).

Potassium is very active in plant water relations, serving in an osmoregulatory capacity. Potassium's role in stomatal opening and closing has been well documented (Meidner and Willmer, 1975). However, research on the effects of K on transpiration rates has produced varying results (Bradbury and Malcolm, 1977; Brag, 1972; Koch and Estes, 1975; Rao and Rao, 1983). Increasing $\mathrm{K}$ fertilization may aid in active osmotic adjustment, which maintains positive turgor pressures at low leaf water potentials and improves the ability of some plant species to avoid drought stress (Lindhauer, 1985; Mengel and Arneke, 1982).

MSC (exposing plants to sublethal dry-down cycles) also has been reported to reduce transpiration and cause osmotic changes that improve avoidance of drought stress. Under well-watered conditions, reductions in transpirational water loss have been reported for several plant species following MSC (Ackerson and Hebert, 1981; Seiler, 1984, 1985). Further, Gupta and Berkowitz (1987) demonstrated that exposing wheat (Triticum aestivum) plants to MSC caused osmotic adjustment and the ability to maintain essential metabolic processes (including gas exchange) at lower leaf water potentials than in plants not previously exposed to MSC.

Although K nutrition and MSC may affect physiological processes directly related to avoidance of drought stress, results have varied. Also no work has been published on potential in-

Received for publication 9 Jan. 1990. From a thesis submitted by D.J.E. in partial fulfillment of the requirements for the $\mathrm{PhD}$ degree. Technical guidance and support from Ronald Eakes and Carol Leda are greatly appreciated. The cost of publishing this paper was defrayed in part by the payment of page charges. Under postal regulations, this paper therefore must be hereby marked advertisement solely to indicate this fact.

'Former Graduate Student. Present address: Dept. of Horticulture, Auburn Univ., AL 36849.

${ }^{2}$ Professor, Dept. of Horticulture.

${ }^{3}$ Assistant Professor, Dept. of Forestry. tractions between $\mathrm{K}$ nutrition and MSC. The objectives of these experiments were to determine the influence of $\mathrm{K}$ nutrition and MSC on water relations, evapotranspiration, and growth of 'Bonfire' salvia.

\section{Materials and Methods}

Growth of plants. Seed of salvia were sown on 5 Aug. 1986 and transplanted 14 days later into $500-\mathrm{ml}$ plastic pots containing a 1 peat : 1 perlite (v/v) medium amended with $1 \mathrm{~kg} \mathrm{Mi-}$ cromax (Sierra Chemical Co., Milpitas, Calif.) and $3 \mathrm{~kg}$ dolomitic limestone $/ \mathrm{m}^{3}$. Plants were grown in a glasshouse under longday conditions [night interruption from 2200 to 0200 HR using incandescent lights providing $\approx 4 \mu \mathrm{mol} \cdot \mathrm{s}^{-1} \cdot \mathrm{m}^{-2}$ photosynthetic photon flux (PPF) at the top of the plant canopies] to extend vegetative growth.

Plants were fertilized with $200 \mathrm{mg} \mathrm{N} / \mathrm{liter}$ as $\mathrm{NH}_{4} \mathrm{NO}_{3}$ and 25 $\mathrm{mg} \mathrm{P} / \mathrm{liter}$ as phosphoric acid in the irrigation water. Potassium concentrations were $25,75,150,300,450$, and $600 \mathrm{mg} \cdot \mathrm{liter}^{-1}$ as $\mathrm{KCl}$. Half of the plants for each $\mathrm{K}$ concentration were subjected to MSC 49 days after seeding by exposing plants to four consecutive sublethal dry-down cycles. This was accomplished by allowing the plants to reach visible wilt [leaf water potential $\left(\psi_{\mathrm{L}}\right)=-1.1$ to $-1.4 \mathrm{MPa}$ before dehydration. Plant water status was monitored during dry-down cycles by determining $\psi_{\mathrm{L}}$ on a single leaf for three randomly selected MSC plants twice daily using a pressure chamber (Scholander et al., 1965). NonMSC plants were watered as needed by applying small amounts of tap water to prevent leaching of nutrients from containers. Post-dry-down dehydration was accomplished by submersing MSC and non-MSC plant containers in their respective nutrient solution for $\approx 20 \mathrm{~min}$.

Treatments for both experiments were arranged in a randomized complete block design with single-plant replicates for each of the 12 treatments $(6 \mathrm{~K} \times 2 \mathrm{MSC})$, with four replications in Expt. 1 and eight in Expt. 2.

\footnotetext{
Abbreviations: EC, electrical conductivity; MSC, moisture stress conditioning; $\mathrm{P}_{\mathrm{L}}$, leaf turgor potential; $\mathrm{PV}$, pressure-volume; $\mathrm{RWC}$, relative leaf water content; SWC, symplastic water content; $\psi_{\mathrm{L}}$, leaf water potential; $\pi_{100}, \pi_{0}$, osmotic potential at full and zero turgor, respectively.
} 
Plant water relations (Expt. 1). Components of plant water relations were estimated using modified pressure-volume (PV) techniques as described by Turner (1981) and Tyree and Jarvis (1982). Plants were irrigated at 2030 and 2400 HR on day 63 to ensure that plants were fully hydrated when predawn observations were initiated the following morning. At $0500 \mathrm{HR}$ on day 64, plants were moved to a darkened laboratory. Single, recently expanded leaves of similar size were removed from each plant with a razor blade, immediately weighed, and then placed in a pressure chamber to determine $\psi_{L}$. Leaf samples were then placed above water in a closed container to retard drying following initial observations. Periodically during the day, each leaf was removed from the container to obtain leaf weight and $\psi_{\mathrm{L}}$. Measurements continued for $\approx 9 \mathrm{~h}$ until leaves were severely wilted (leaf weights were $70 \%$ to $85 \%$ of the initial leaf weight). The leaves were then oven-dried and weighed.

PV curves were constructed for each leaf by plotting the reciprocal of $\psi_{\mathrm{L}}$ (ordinate) against the corresponding leaf relative water content (RWC). RWC $=[$ (subsequent fresh weight dry weight)/(initial fresh weight - dry weight)] $\times 100$. The equation for the linear portion of each PV curve was determined through regression analysis, while the curvilinear portion of each graph was estimated. Symplastic water content (SWC) was calculated by subtracting the $\mathrm{x}$-intercept of the line from 100 (RWC at full turgor), while $\pi_{100}$ was determined as the inverse of the y-intercept. $\pi_{0}$ was estimated as the point at which the linear and curvilinear portions of the PV curve joined. Leaf turgor potential $\left(\mathrm{P}_{\mathrm{L}}\right)$ for each $\psi_{\mathrm{L}}$ observation was calculated based on the equation. described by Hsiao (1973): $\psi_{\mathrm{L}}=\psi+\mathrm{P}_{\mathrm{L}}$.

Following removal of leaf samples for estimation of components of plant water relations, plants were returned to the greenhouse and water was withheld to observe wilting. Visual observations were made on days 64 and 65.

Medium and plant components measured (Expt. 2). The day of final dehydration, 63 days after transplanting, medium solution samples were collected using the pour-through extraction method (Wright, 1987) to determine medium solution electrical conductivity (EC) and K concentration. EC (soluble salt levels) was determined using the Agri-Meter (Myron L Co., Carlsbad, Calif.). Potassium medium solution concentrations were determined using atomic absorption spectrophotometry.

On day 65, evapotranspiration was determined gravimetritally. Pots were irrigated at $0545 \mathrm{HR}$ and allowed to drain until leachate ceased before initial pot weights were taken (0645 HR). Final pot weights were determined at 1645 HR. Total leaf area was determined for each plant at the termination of the experiment using a LI-COR (Lincoln, Neb.) Model LI-3000 portable leaf area meter. Evapotranspiration per unit leaf area was then calculated for the $10 \mathrm{~h}$.

Plant stems were then cut at the soil line to determine shoot dry weight. Recently matured leaves were collected to determine foliar $\mathrm{K}$ concentrations using atomic absorption spectrophotometry.

Data analysis. All data were subjected to analysis of variance (ANOVA) and regression analysis. Homogeneity for regression coefficients of linear regressions for the relationship of $\mathrm{P}_{\mathrm{L}}$ to $\psi_{\mathrm{L}}$ and of osmotic potential to $\mathrm{K}$ concentration were tested by $t$ test.

\section{Results}

Plant water relations. MSC and $\mathrm{K}$ had an interactive influence on $\pi_{100}$ and $\pi_{0}$ (Fig. 1). Differences between MSC and non-MSC plants for each of these characteristics increased with increasing K concentrations. SWC was not affected by treatment
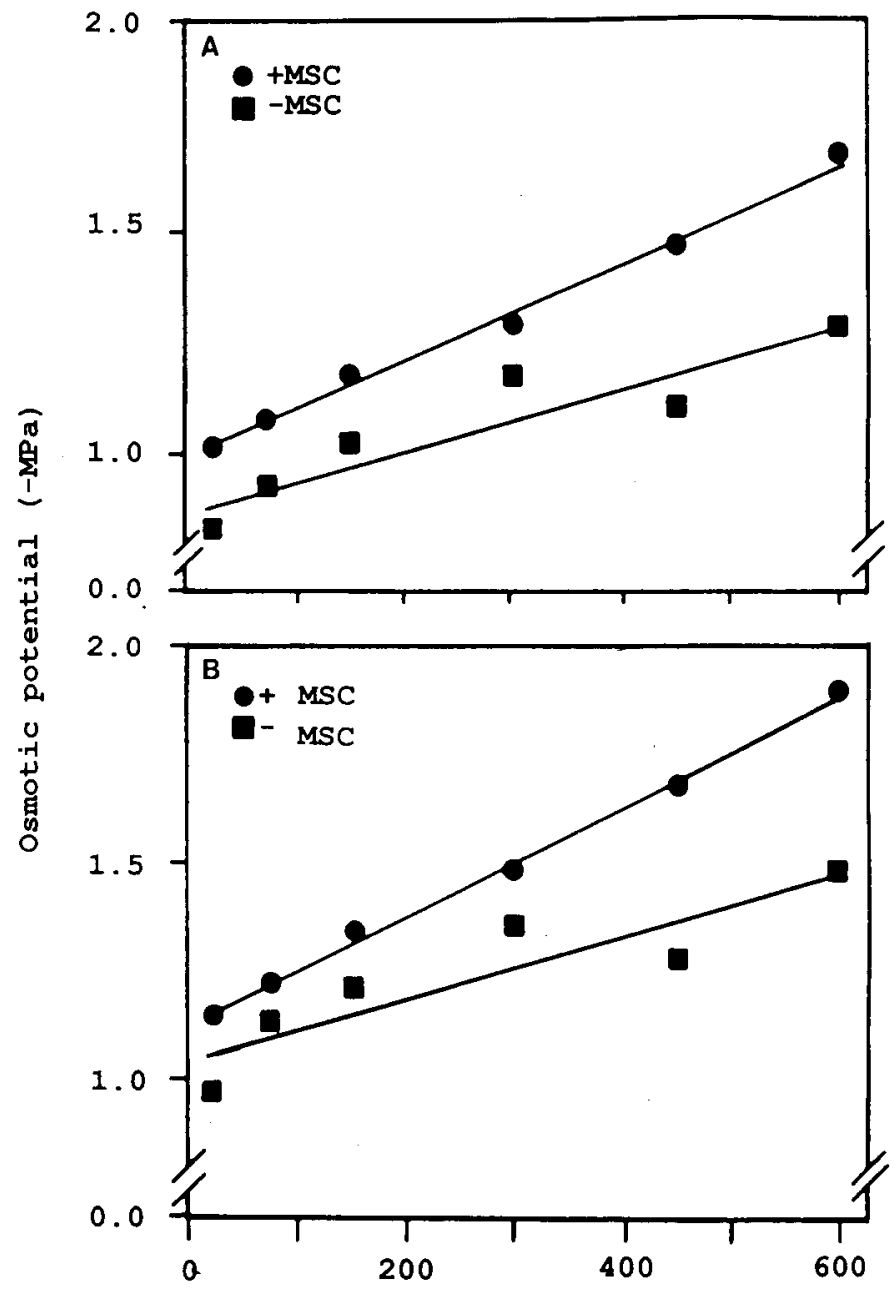

$\mathrm{K}$ concentration $\left(\mathrm{mg} . \mathrm{1}^{-1}\right)$

Fig. 1. Leaf osmotic potential at full (A) and zero (B) turgor of Salvia splendens 'Bonfire' as influenced by $\mathrm{K}$ concentration and MSC. Osmotic potential at full turgor: + MSC, $\mathrm{y}=0.99+0.0011 \mathrm{x}, R^{2}$ $=0.91^{* * *}$ and $-\mathrm{MSC}, \mathrm{y}=0.86+0.0007 \mathrm{x}, R^{2}=0.80^{* *} ; b_{0}^{* *}$ and $b_{1} * *$. Osmotic potential at zero turgor: + MSC, $\mathrm{y}=1.13+$ $0.0012 \mathrm{x}, R^{2}=0.92 * *$ and $-\mathrm{MSC}, \mathrm{y}=1.05+0.0007 \mathrm{x}, R^{2}=$ $0.74^{* * *} ; b_{0}^{*}$ and $b_{1}^{* *}$. Linear regression coefficients (y-intercept $=$ $b_{0}$; slope $=b_{l}$ ) significantly different at $P=0.05\left({ }^{*}\right)$ or $0.01\left(^{* *}\right)$.

(data not shown). $\mathrm{P}_{\mathrm{L}}$ was always higher at any given $\psi_{\mathrm{L}}$ in MSC plants, and differences in $\mathrm{P}_{\mathrm{L}}$ became greater as $\mathrm{K}$ concentration increased (Fig. 2, Table 1).

Medium and plant components. No interactions between $\mathrm{K}$ and MSC were observed for evapotranspiration on a per-plant or unit-leaf-area basis. Evapotranspiration per unit leaf area decreased linearly as $\mathrm{K}$ concentration increased, while per-plant evapotranspiration rate increased in response to $\mathrm{K}$ concentrations up to $150 \mathrm{mg} \cdot$ liter $^{-1}$ but not beyond (Table 2). MSC plants compared to non-MSC plants had a $30 \%$ reduction in evapotranspiration per unit leaf area and a $32 \%$ reduction on a per-plant basis.

Shoot dry weight was significantly affected by K and MSC in the absence of an interaction (Table 2). Maximum observed dry weight yield occurred at $300 \mathrm{mg}$ K/liter, while MSC inhibited dry weight accumulation by $\approx 27 \%$ compared to non-MSC plants when averaged over the six $\mathrm{K}$ concentrations. Total leaf area per plant increased linearly with increasing $\mathrm{K}$ concentrations. MSC had little effect on leaf area. 

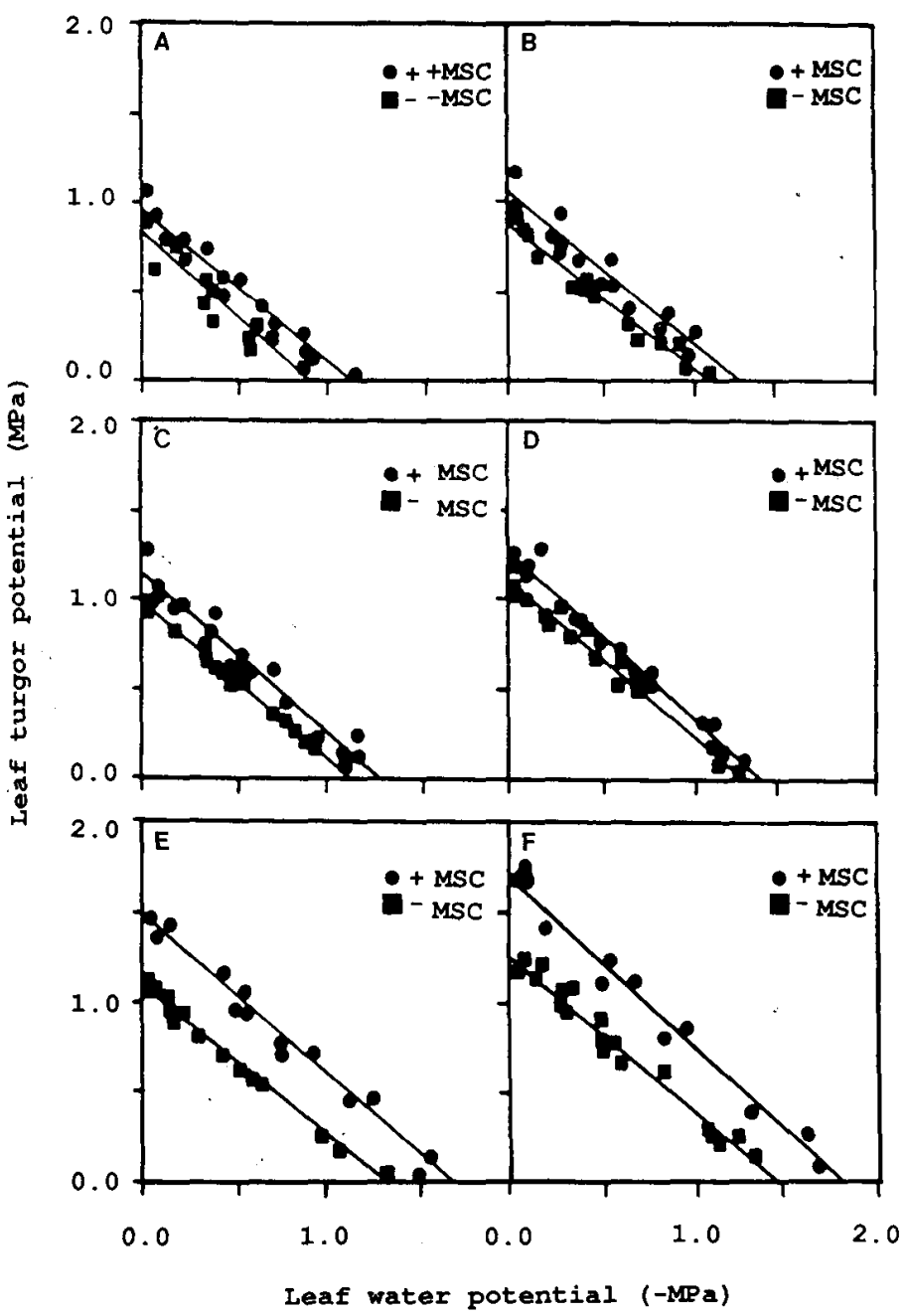

Fig. 2. The relationship between leaf turgor potential and water potential of Salvia splendens 'Bonfire' as influenced by $\mathrm{K}$ concentration and MSC. $\mathrm{K}=25 \mathrm{mg} \cdot \operatorname{liter}^{-1}(\mathbf{A}):+\mathrm{MSC}, \mathrm{y}=0.97-0.86 \mathrm{x}$, $r=0.98^{* *}$ and $-\mathrm{MSC}, \mathrm{y}=0.83-0.89 \mathrm{x}, r=0.98^{* *} ; b_{0}{ }^{* *}$ and $b_{1}{ }^{\mathrm{NS}} . \mathrm{K}=75 \mathrm{mg} \cdot \operatorname{liter}^{-1}(\mathrm{~B}):+\mathrm{MSC}, \mathrm{y}=1.04-0.84 \mathrm{x}, r$ $=0.96^{* *}$ and $-\mathrm{MSC}, \mathrm{y}=0.86-0.79 \mathrm{x}, r=0.98^{* *} ; b_{0}{ }^{* *}$ and $b_{1}{ }^{\mathrm{NS}} . \mathrm{K}=150 \mathrm{mg} \cdot \operatorname{liter}^{-1}(\mathbf{C}):+\mathrm{MSC}, \mathrm{y}=1.15-0.89 \mathrm{x}, r=$ $0.97^{* *}$ and $-\mathrm{MSC}, \mathrm{y}=0.99-0.85 \mathrm{x}, r=0.99^{* *} ; b_{0}^{* *}$ and $b_{1}{ }^{\mathrm{NS}} . \mathrm{K}=300 \mathrm{mg} \cdot \mathrm{liter}^{-1}(\mathrm{D}):+\mathrm{MSC}, \mathrm{y}=1.27-0.92 \mathrm{x}, r=$ $0.99^{* *}$ and $-\mathrm{MSC}, \mathrm{y}=1.11-0.85 \mathrm{x}, r=0.99^{* *} ; b_{0}{ }^{* *}$ and $b_{1}{ }^{\text {NS }} . \mathrm{K}=450 \mathrm{mg} \cdot \mathrm{liter}^{-1}(\mathbf{E}):+\mathrm{MSC}, \mathrm{y}=1.46-0.90 \mathrm{x}, r=$ $0.99^{* *}$ and $-\mathrm{MSC}, \mathrm{y}=1.08-0.84 \mathrm{x}, r=0.99^{* *} ; b_{0}{ }^{* *}$ and $b_{1}{ }^{\text {Ns }} . \mathrm{K}=600 \mathrm{mg} \cdot$ liter $^{-1}(\mathbf{F}):$ + MSC, $\mathrm{y}=1.67-0.93 \mathrm{x}, r=$ $0.99^{* *}$ and $-\mathrm{MSC}, \mathrm{y}=1.25-0.88 \mathrm{x}, r=0.99^{* *} ; b_{0}{ }^{* *}$ and $b_{1}{ }^{\text {NS }}$. Linear regression fit significant at $P=0.01\left({ }^{* *}\right)$. Regression coefficients (y-intercept $=b_{0}$; slope $=b_{1}$ ) not significant (NS) or significant at $P=0.01\left({ }^{* *}\right)$.

MSC by $\mathrm{K}$ interactions occurred for medium solution EC, medium solution $\mathrm{K}$ concentration, and foliar $\mathrm{K}$ concentration (Table 3). Each of these three measurements increased linearly with increasing $\mathrm{K}$ concentrations for both MSC and non-MSC plants. MSC plants had greater medium solution EC, medium solution $\mathrm{K}$ concentration, and foliar $\mathrm{K}$ concentration compared to non-MSC plants.

\section{Discussion}

The changes in $\pi_{100}$ and $\pi_{0}$ with no change in SWC (osmotically active water) indicates that salvia actively adjusted os-
Table 1. Comparison of linear regression coefficients $(y$-intercept $=$ $b_{0}$; slope $=b_{1}$ ) for the relationship between leaf turgor pressure and water potential of Salvia splendens 'Bonfire' as influenced by $\mathrm{K}$ concentration and MSC.

\begin{tabular}{|c|c|c|c|c|c|c|}
\hline \multirow{2}{*}{$\begin{array}{l}\text { K concn } \\
\left(\mathrm{mg} \cdot \text { liter }^{-1}\right)\end{array}$} & \multirow{2}{*}{$\begin{array}{l}\text { Regression } \\
\text { coefficient }\end{array}$} & \multicolumn{5}{|c|}{$\mathrm{K}$ concn (mg $\cdot$ liter $\left.^{-1}\right)$} \\
\hline & & 75 & 150 & 300 & 450 & 600 \\
\hline \multirow{3}{*}{25} & & \multicolumn{5}{|c|}{$+M S C$} \\
\hline & $b_{0}$ & NS & $* *$ & $* *$ & $* *$ & $* *$ \\
\hline & $b_{1}$ & NS & NS & NS & NS & NS \\
\hline \multirow[t]{2}{*}{75} & $b_{0}$ & -- & $* *$ & $* *$ & $* *$ & $* *$ \\
\hline & $b_{1}$ & --- & NS & NS & NS & NS \\
\hline \multirow[t]{2}{*}{150} & $b_{0}$ & --- & -- & $* *$ & $* *$ & $*$ \\
\hline & $b_{1}$ & --- & --- & NS & NS & NS \\
\hline \multirow[t]{2}{*}{300} & $b_{0}$ & --- & $\cdots$ & $\cdots$ & $* *$ & NS \\
\hline & $b_{1}$ & --- & --- & $\cdots$ & NS & $*$ \\
\hline \multirow[t]{2}{*}{450} & $b_{0}$ & --- & -- & $\cdots$ & -- & $* *$ \\
\hline & $b_{1}$ & $\cdots$ & --- & - & -- & $*$ \\
\hline \multirow{3}{*}{25} & & & & $-M S C$ & & \\
\hline & $b_{0}$ & NS & $* *$ & $* *$ & $* *$ & $* *$ \\
\hline & $b_{1}$ & NS & NS & NS & NS & NS \\
\hline \multirow[t]{2}{*}{75} & $b_{0}$ & --- & $* *$ & $* *$ & $* *$ & $* *$ \\
\hline & $b_{1}$ & -- & NS & NS & NS & NS \\
\hline \multirow[t]{2}{*}{150} & $b_{0}$ & --- & -- & $* *$ & $* *$ & $* *$ \\
\hline & $b_{1}$ & --- & --- & NS & NS & NS \\
\hline \multirow[t]{2}{*}{300} & $b_{0}$ & $\cdots$ & -- & -- & NS & $* *$ \\
\hline & $b_{1}$ & --- & --- & --- & NS & NS \\
\hline \multirow{2}{*}{450} & $b_{0}$ & --- & --- & --- & -- & $* *$ \\
\hline & $b_{1}$ & $\cdots$ & $\cdots$ & $\cdots$ & -- & NS \\
\hline
\end{tabular}

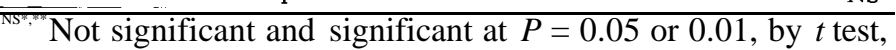
respectively.

Table 2. Evapotranspiration, shoot dry weight, and total leaf area of Salvia splendens 'Bonfire' as influenced by K concentration and moisture stress conditioning (MSC).

\begin{tabular}{|c|c|c|c|c|}
\hline \multirow[b]{2}{*}{ Treatment } & \multicolumn{2}{|c|}{ Evapotranspiration $^{z}$} & \multirow{2}{*}{$\begin{array}{c}\text { Shoot } \\
\text { dry wt } \\
\text { (g) }\end{array}$} & \multirow{2}{*}{$\begin{array}{c}\text { Total } \\
\text { leaf area } \\
\left(\mathrm{cm}^{2}\right)\end{array}$} \\
\hline & $\begin{array}{c}\text { Leaf area } \\
\left(\mathrm{mg} \cdot \mathrm{cm}^{-2}\right)\end{array}$ & $\begin{array}{c}\text { Plant } \\
\text { (g) }\end{array}$ & & \\
\hline \multicolumn{5}{|c|}{$\mathrm{K}$ concn $\left(\mathrm{mg} \cdot\right.$ liter $\left.^{-1}\right)$} \\
\hline 25 & 120 & 77 & 4.5 & 650 \\
\hline 75 & 119 & 89 & 5.1 & 740 \\
\hline 150 & 128 & 103 & 5.3 & 810 \\
\hline 300 & 112 & 101 & 5.4 & 900 \\
\hline 450 & 109 & 100 & 5.2 & 920 \\
\hline 600 & 101 & 99 & 5.2 & 1030 \\
\hline \multicolumn{5}{|l|}{ MSC } \\
\hline+ & 95 & 77 & 4.3 & 820 \\
\hline- & 135 & 113 & 5.9 & 860 \\
\hline \multicolumn{5}{|l|}{$\begin{array}{l}\text { Significance } \\
\mathrm{K} \text { concn }\end{array}$} \\
\hline Regression ${ }^{y}$ & $\mathrm{~L}^{*}$ & $Q^{*}$ & $Q^{*}$ & $\mathrm{~L}^{* *}$ \\
\hline$R^{2}$ & 0.08 & 0.13 & 0.12 & 0.45 \\
\hline MSC & $* *$ & $* *$ & $* *$ & NS \\
\hline
\end{tabular}

${ }^{\mathrm{z}}$ Accumulative water loss from 0800 to $1800 \mathrm{HR}$.

yLinear (L) and quadratic $(\mathrm{Q})$ regression fits at $P=0.05\left(^{*}\right)$ or 0.01 $\left({ }^{* *}\right)$.

Ns,** Not significant and significant at $P=0.01$, respectively, by $\mathrm{F}$ test.

motically in response to increasing $\mathrm{K}$ nutrition and MSC (Hsiao, 1973; Weatherley, 1970). Although increasing K concentration (Lindhauer, 1985; Mengel and Arneke, 1982) and moisture stress (Ackerson and Hebert, 1981; Jones and Turner, 1980; Seiler, 1985; Turner et al., 1987) have been separately reported to 
Table 3. Medium solution EC, medium solution $\mathrm{K}$ concentration, and foliar K concentration of Salvia splendens 'Bonfire' as influenced by $\mathrm{K}$ concentration and MSC.

\begin{tabular}{|c|c|c|c|c|c|c|}
\hline \multirow[b]{2}{*}{ Treatment } & \multicolumn{2}{|c|}{$\begin{array}{l}\text { Medium } \\
\text { solution EC } \\
\left(\mathrm{d} S \cdot \mathrm{m}^{-1}\right)\end{array}$} & \multicolumn{2}{|c|}{$\begin{array}{c}\text { Medium } \\
\text { solution K } \\
\left(\mathrm{mg} \cdot \text { liter }^{-1}\right)\end{array}$} & \multicolumn{2}{|c|}{$\begin{array}{c}\text { Foliar K } \\
(\%)\end{array}$} \\
\hline & $+\mathrm{MSC}$ & -MSC & $+\mathrm{MSC}$ & $-\mathrm{MSC}$ & $+\mathrm{MSC}$ & $\dot{-M S}$ \\
\hline \multicolumn{7}{|c|}{$\mathrm{K}$ concn $\left(\mathrm{mg} \cdot\right.$ liter $\left.^{-1}\right)$} \\
\hline 25 & $1.20^{\mathrm{z}}$ & 0.95 & 17 & 16 & 1.28 & 0.93 \\
\hline 75 & 1.23 & 1.18 & 48 & 36 & 2.18 & 1.28 \\
\hline 150 & 1.88 & 1.25 & 134 & 82 & 3.55 & 2.08 \\
\hline 300 & 2.73 & 1.65 & 367 & 158 & 4.75 & 4.10 \\
\hline 450 & 3.70 & 2.45 & 633 & 415 & 5.53 & 4.88 \\
\hline 600 & 4.65 & 3.05 & 852 & 672 & 6.10 & 5.50 \\
\hline \multicolumn{7}{|l|}{ Significance } \\
\hline Regression ${ }^{y}$ & $\mathrm{~L}^{* *}$ & $\mathrm{~L}^{* *}$ & $\mathrm{~L}^{* *}$ & $\mathrm{~L}^{* *}$ & $\mathrm{~L}^{* *}$ & $\mathrm{~L}^{* *}$ \\
\hline$R^{2}$ & 0.96 & 0.88 & 0.95 & 0.92 & 0.91 & 0.94 \\
\hline
\end{tabular}

${ }^{\mathrm{z}}$ Differences due to MSC at each $\mathrm{K}$ concentration are significant at $P$ $=0.01$ by $\mathrm{F}$ test.

Significant linear regression fit at $P=0.01$.

cause osmotic adjustment in some plants, our results show a synergistic effect between increasing $\mathrm{K}$ and MSC.

Osmotic changes for salvia in response to increasing $\mathrm{K}$ concentration and MSC resulted in plants that were able to maintain positive $\mathrm{P}_{\mathrm{L}}$ to lower $\psi_{\mathrm{L}}$ than plants grown with low $\mathrm{K}$ concentrations and non-MSC. In fact, before plants were harvested on day 65 , those plants grown with increasing $\mathrm{K}$ concentrations and MSC wilted later as moisture deficits developed than plants grown with low K and non-MSC (data not shown). Maintenance of $\mathrm{P}_{\mathrm{L}}$-dependent physiological processes, including gas exchange, at low $\psi_{\mathrm{L}}$ due to osmotic adjustment has been shown with increasing $\mathrm{K}$ concentration (Lindhauer, 1985), as well as following MSC (Ackerson and Hebert, 1981; Gupta and Berkowitz, 1987; Seiler, 1984, 1985; Turner et al., 1978).

Water deficits were apparently not responsible for treatment differences observed for evapotranspiration in this study. Mean $\psi_{\mathrm{L}}$ of plants used for gravimetric water loss measurements was - 0.67 MPa, while the onset of stomatal closure for herbaceous dicots has reportedly occurred at $\psi_{\mathrm{L}}$ from -0.7 to $-1.6 \mathrm{MPa}$ (Hsiao, 1973). Reductions in evapotranspiration following MSC may be attributable to accumulation of abscisic acid (ABA) during dry-down cycles, a phenomenon known to cause stomatal closure (Meidner and Willmer, 1975).

Total leaf area increased linearly with increasing K concentration. However, evapotranspiration per unit leaf area declined with increasing $\mathrm{K}$ concentration, and evapotranspiration per plant did not increase beyond $150 \mathrm{mg} \mathrm{K} / \mathrm{liter}$. Reasons for reductions in evapotranspiration with high $\mathrm{K}$ concentrations despite increasing leaf area could include: reduced stomatal apertures, leaf size or arrangement causing differences in boundary layer resistance to transpirational water loss or mutual shading, and/ or higher $\mathrm{K}$ concentrations in the tissue causing stomata to be more sensitive to environmental conditions (Bradbury and Malcolm, 1977)..

The ability of plants to withstand the onset of drought depends on economical water use and their ability to maintain turgor. Results from this work indicate that increasing $\mathrm{K}$ concentration, MSC, or a combination of the two should improve the ability of salvia to avoid drought stress through physiological accli- mations that reduce evapotranspiration and cause active osmotic adjustment.

\section{Literature Cited}

Ackerson, R.C. and R.R. Hebert. 1981. Osmoregulation in cotton in response to water stress. Plant Physiol. 67:484-488.

Bradbury, I.K. and D.C. Malcolm. 1977. The effect of phosphorus and potassium on transpiration, leaf diffusive resistance and water use efficiency in sitka spruce (Picea sitchensis)) seedlings. J. Appl. Ecol. 14:631-641.

Brag, H. 1972. The influences of potassium on the transpiration rate and stomatal opening in Triticum aestivum and Pisum sativum. Physiol. Plant. 26:250-257.

Gupta, A.S. and G.A. Berkowitz. 1987. Osmotic adjustment, symplast volume, and nonstomatally mediated water stress inhibition of photosynthesis in wheat. Plant Physiol. 85:1040-1047.

Hsiao, T.C. 1973. Plant responses to water stress. Annu. Rev. Plant Physiol. 24:519-570.

Jones, M.M. and N.C. Turner. 1980. Osmotic adjustment in expanding and fully expanded leaves of sunflower in response to water deficits; Austral. J. Plant Physiol. 7:181-192.

Koch, D.W. and G.O. Estes. 1975. Influence of potassium stress on growth, stomatal behavior and $\mathrm{CO}_{2}$ assimilation in corn. Crop Sci. 15:697-699.

Kramer, P.J. 1983. Water relations of plants. Academic, New York.

Lindhauer, M.G. 1985. Influence of K nutrition and drought on water relations and growth of sunflower (Helianthus annuus L.). Z. Pflanzenernaehr Bodenk. 148:654-669.

Meidner, H. and C. Willmer. 1975. Mechanics and metabolism of guard cells. Current Adv. Plant Sci. 17:1-15.

Mengel, K. and W.W. Ameke. 1982. Effect of potassium on the water potential, the pressure potential, the osmotic potential and cell elongation in leaves of Phaseolus vulgaris. Physiol. Plant. 54:402-408.

Mengel, K. and E.A. Kirkby. 1982. Principles of plant nutrition. International Potash Inst., Bern, Switzerland.

Rae, K.V. and K.V.M. Rae. 1983. Influence of potassium nutrition on stomatal behavior, transpiration rate and leaf water potential of pigeon pea (Cajanus cajan (L.) Millsp.) in sand culture. Proc. Indian Acad. Sci. (Plant Sci.) 92:323-330.

Scholander, P.F., H.T. Hammel, E.D. Bradstreet, and E.A. Hemmingsen. 1965. Sap pressure in vascular plants. Science 148:339346.

Seiler, J.R. 1984. Physiological response of loblolly pine seedlings to moisture-stress conditioning and their subsequent performance during water stress. PhD Diss., Virginia Polytechnic Inst. and State Univ. (Diss. Abstr. DA8425794)

Seiler, J.R. 1985. Morphological and physiological changes in black alder induced by water stress. Plant, Cell \& Env. 8:219-222.

Turner, N.C. 1981. Techniques and experimental approaches for the measurement of plant water status. Plant \& Soil 58:339-366.

Turner, N.C., J.E. Begg, and M.L. Tonnet. 1978. Osmotic adjustment of sorghum and sunflower crops in response to water deficits and its influence on the water potential at which stomata close. Austral. J. Plant Physiol. 5:597-608.

Turner, N.C., W.R. Stem, and P. Evans. 1987. Water relations and osmotic adjustment of leaves and roots of lupins in response to water deficits. Crop Sci. 27:977-983.

Tyree, M.T. and P.G. Jarvis. 1982. Water in tissues and cells, p. 3577. In: O.L. Lange, P.S. Nobel, C.B. Osmond, and H. Ziegler (eds.). Encyclopedia of plant physiology. vol. 12B. Springer, Berlin.

Weatherley, P.E. 1970. Some aspects of water relations. Adv. Bot. Res. 3:171-206.

Wright, R.D. 1987. The Virginia Tech liquid fertilizer system for container grown plants. Virginia Tech College of Agriculture and Life Sciences Info. Ser. 86-5. 